\title{
a FEW NOTES ON THE HISTORY OF SOCIAL ò OWNERSHIP IN THE SPHERES OF CULTURE AND FILM IN SOCIALIST YUGOSLAVIA FROM

\section{Gal Kirn}

Institut for Slavistics, Humboldt University of Berlin

\begin{abstract}
This text critically evaluates how the idea of self-management changed and materialized in Yugoslavia, especially during the sixties and seventies. The first section presents a general overview of politics concerning self-management and its paradoxical and contradictory unfolding, while the second section focuses on the contours of the Yugoslav cultural sphere, especially in the field of film from the late fifties to the early seventies. More concretely, the author intends to sketch the ways in which social ownership and self-management forms were inscribed in cultural infrastructure and budget planning, drawing attention to the precarious status of cultural work.
\end{abstract}

Key words: Yugoslav self-management, social ownership, cultural infrastructure, film industry, 1960s-1970s, cultural work

\section{Introduction}

When mainstream ideological discourse pays attention to the name of the socialist Yugoslavia, it either forces us to violently forget it and reduce it to the "totalitarian" past, or it idealizes the good old times, where Tito's rule worked for the benefit of all. This ideological duo of anti-totalitarian and Yugonostalgic discourse not only reduces the historical complexity of the socialist past, but even to a certain degree blocks any thought of an emancipatory present and/or future, standing as an apologetic of the past or present times. What follows should therefore not be read as part of a (Yugo)nostalgic account, but rather as intending to launch both a critical and affirmative evaluation of the politics of self-management, which today deserves a more precise historicization and contextualisation. I wish to join in with the assessments made by theorists such as Dolenec and Žitko ${ }^{1}$ and the most recent study of Suvin (2014), who tackle the problem of theoretical reflection on self-management and social property as constitutive for understanding socialism, and particularly the Yugoslav experiment. Anyone who is interested in the emancipatory and leftist reading of struggles for the commons and critiques of a contemporary crisis of the capitalist mode of production, should also evaluate and compare concrete historical experiences that attempted to invent both an anti-capitalist and anti-state mode of regulation. Let us not forget that the Yugoslav self-management project was initiated in a time of isolation from the West and East. ${ }^{2}$

In order to critically evaluate how the idea of self-management changed and materialized, I will first give a general overview of self-management politics and its paradoxical unfold-

${ }^{1}$ Dolenec and Žitko's text convincingly tackles the importation of the problem of commons in the Yugoslav context: they suggest that social ownership already was a form of commons, and that it was connected to a larger anti-capitalist project that strives for the abolition of private property (2013). The theory of commons is nowadays mostly associated with the work of Hardt and Negri (2009). For a good criticism see also Harvey (2010).

${ }^{2}$ Apart from the afore-mentioned studies my own dissertation analyzes the details concerning the transition after 1965 and the market reform (Kirn 2012a). 
ing, while in the second part I shall focus on the contours of the Yugoslav cultural scene, especially in the field of film from the late 1950s to the early 1970s. ${ }^{3}$ The introduction of social property and self-management forms will be evaluated via the nascent cultural infrastructure, budget planning and the status of cultural workers. Some of the following theses will remain cursory; because of the spatial limit I cannot give a more precise statistical and historical analysis, but I will emphasize the most vital shifts within cinematic production and organisation over the sixties and seventies.

\section{A Few Notes on Self-Management and Social Ownership}

Yugoslavian socialist self-management was born in the early 1950s and moved both ideologically and politically beyond the dichotomy of state and market, in many respects contributing to the invention of a specific form of ownership: social ownership. One can immediately object that workers' self-management was imposed "from above", by the communist leadership. However, even if this was true on the formal level of laws and control of the party, one should nevertheless trace the causes of the emergence of self-management from the split with Stalin and the Informbiro in 1948. After this ex-communication, Yugoslavia became isolated from the West and East and the policy of workers' self-management was designed to sustain strong popular support for the Yugoslav independent path to socialism. Taken from a more theoretical perspective, ${ }^{4}$ self-management can be defined as a political practice that targeted two major points: on the one hand it continued to dismantle capitalist exploitation; while on the other hand, it exerted an internal critique within the international workers' movement targeting state socialism and a hierarchical nationalized planned economy that minimized workers' democratic forms. Despite internal strife within the Communist Party over a clear future orientation for the Party, the argument against state ownership won ${ }^{5}$ and the politics of the "nationalization" of economic capacities and infrastructure was identified as consisting of excessive bureaucratic control, thus constituting a (gradual) defeat of the path to communism. As regards the realization of communism, Yugoslav communists called for a return to Lenin and his idea of a "withering away of state". 6 This demanded not only a critique of bureaucratic control, but also a real process that moved away from "nationalization" to "socialization" of the means of production and consequently, also of the means of reproduction. In 1950 the first formal step was taken when adopting the Basic Law on Management of State Economic Enterprises and Higher Economic Associations by the Workers' Collective, ${ }^{7}$ while the politics of self-management had long-term consequences for socialist reproduction and development in Yugoslavia.

For the sake of brevity one should emphasize that this reform introduced new political forms - workers' councils - into all production units (socialist enterprises), where the majority consisted of employees/workers, and who would also delegate their members to higher

\footnotetext{
${ }^{3}$ I will mostly leave out the first two periods of the Yugoslav film history; the early after-war years were mostly marked by the centralized studio and funding system with strong ideological control, while the 1950 s were marked by a gradual decentralisation. For a good film history of these periods see Goulding (2001: 32-61), and Kosanović (1966).

${ }^{4}$ Marković, one of philosophers from Marxist-Praxis school gave a good analysis of the theoretical sources of socialist self-management (1975).

${ }^{5}$ Boris Kidrič was the chief political economist and minister for the economy, who most openly called for the critique of state socialism. For a lucid interpretation see Suvin (2014: 61-66).

${ }^{6}$ For a good comment on and historical evaluation of this politics see also Samary (1988).

${ }^{7}$ The summary of the most important points of this law can be found in English at: https://www.marxists.org/subject/yugosla$\mathrm{via} /$ self-management/1950/06/x01.htm.
} 
political levels of workers' representation. Unquestionably, the policy of self-management was adapted to historical circumstances and political discussions, and became a dominant ideology into which many different ideological forms translated. One of the central features of the self-management model was its constant renewal, but that does not mean that the development unfolded without contradictions and transitions. Socialism in its immanent constellation is a compromise form, which combines capitalist and communist elements, thus presenting a mixed economy. Broadly, we could argue that at least until the mid 1960s, the politics of self-management proved to be successful in improving material infrastructure, well-being and the life of the vast majority of people in Yugoslavia, while over the last two decades we have seen the process of the exhaustion of communist politics. ${ }^{8}$

In the reality of the 1950s, the self-management model stood mostly for the empowerment of workers in the organization of economic units, while on a more political level self-management was identified with the process of decentralization. This meant a gradual empowerment of the lower levels of governing, such as republics and (municipal and local) communities, who fought against the bureaucratic monopoly of political and economic power. It also meant a proliferation of self-management forms into other non-economic fields of society: culture, science, health system, education, housing and so forth. In terms of political economy, what used to be regulated by a more homogenous bureaucratic force that disposed with social capital in the name of working class was now more and more decentralized. Instead of bureaucracy we can locate technocracy (a social strata of experts and directors in factories, bank managers) as the agency that managed multiple independent capitals. Thus, we can define "social ownership" as a paradoxical formation, whereby the means of production, land, (social) housing did not belong to anyone, but to the whole society. As Rastko Močnik claimed, "social ownership could have been able to permit the opening up of new horizons in the matter of political practices, if its political potential had not been sapped by the apparatuses of social management" (2010). Moreover, the legal theorist Drago Bajt spoke about the "double inscription" of social ownership into legal and economic aspects, which meant that "legally enterprise would be the owner of the means of production, whereas the workers would manage it in reality. The workers' collective was then the economic owner of the means of production" (Bajt 1975: 159). In other words, the enterprise had the "right of disposal", while the workers' collective had "managing rights". The major obstacle in the regime of social property was located in the improper institutional solution that might properly implement this division of ownership rights between the workers' collective and enterprise. The sociologist Veljko Rus claims that:

the workers' collective would decide about matters that relate to management, while the enterprise or rather its representatives would decide on matters that related to disposal. If workers themselves would accumulate means/resources in their working organisation, then they would be also the owners of the enterprise's capital, while if these means would be invested by other subjects, e.g. banks, foreign investors etc., then they would have the disposal rights. (Rus 1988: 19)

Due to its formal vagueness, social property very early on hit multiple political and "structural" obstacles: from the mixing of workers' political participation with the shareholding tendency to a greater role that would be played by the market, that is, by the strengthening of the capitalist tendency which would push it in the direction of private property. The loca-

\footnotetext{
${ }^{8}$ Again this evaluation and schematic split on Yugoslavia before 1965 and after 1965 relies mostly on the works of Kirn (2012a) and Suvin (2014).
} 
tion of class struggle was concentrated much less around the form and question of property, and much more around the question of management, appropriation and the distribution of value. This was the key site where the paradox of self-management could be located.

\begin{tabular}{|l|l|l|}
\hline Self-managed worker(s) & $><$ & Self-managed community \\
\hline $\begin{array}{l}\text { Founding moment: "total" alienation of } \\
\text { means of production, nationalisation of } \\
\text { industry }\end{array}$ & Exchange & $\begin{array}{l}\text { State property } \\
\text { After } 1950 \text { social property (paradox of property in } \\
\text { hands of none and all members of society) }\end{array}$ \\
\hline $\begin{array}{l}\text { Workers: labour force } \\
\text { (production) }\end{array}$ & $\begin{array}{l}\text { appropriation of surplus } \\
\text { value }\end{array}$ & $\begin{array}{l}\text { State: proponents bureaucracy/ (planning) } \\
\text { (organisation) }\end{array}$ \\
\hline 2. Schema of political power & $\begin{array}{l}\text { Representation of self- } \\
\text { managed interests }\end{array}$ & $\begin{array}{l}\text { Bureaucracy - political representatives } \\
\text { Technocracy - } \text { economic representatives }\end{array}$ \\
Working people; self-managers
\end{tabular}

Schema of the Social Contract of the Self-managed Community

The major shift within the socialist transition took place in the period of so-called "market socialism", which came into existence after 1965. Market reform was executed in the name of democratization and decentralization and the broadening of self-management rights, which eventually led to a real transfer of political and economic power. But what did this mean in politico-economic practice? Formally, it meant that workers could now have more say over their own wage, thus they participated directly in the question of the distribution of surplus value. But was it really workers, who decided upon key questions such as: who, what and how to produce and re-invest? Rather than bureaucracy, it was technocracy which gained the upper hand in the sphere of production. We might agree with the following general assessment by Diane Flaherty:

However, by defining self-management as autonomy of the smallest production unit (...) reforms decentralized to the point that conscious coordination of any sort was rendered virtually impossible ... Each new decentralization pitted ever larger numbers of ever smaller production units against each other, sacrificing inter-unit cooperation for expected improvement in intra-unit equality. Market reforms at the same time had already increased competitive pressure on self-managed firms and BOALS, reducing the expected gains in intra-unit equality as firms turned to experts to save them from failure in the face of chaotic market conditions. (11)

In other words, production units increasingly followed market criteria, which meant the maximisation of surplus value, which not only produced stronger competition among production units, but also between workers. Susan Woodward (1995) rightly showed that the market reform actually reduced the level of employment, since the enterprises secured the accumulated value and conserved the privileges, rather than employing new labour power.

Apart from changes in the regime of accumulation of independent capital on the level of enterprise, decentralization empowered individual republics, which de facto became bearers of political and economic sovereignty. The federation was becoming a confederation as early as the late 1960 s and the socio-economic mechanisms for solidarity that were earlier 
sustained on the federal level - via the National Bank and Fund for Development - were bracketed. ${ }^{9}$ With integration into global financial circuits, the monetary capacities and power to give credits were vested into (commercial) banks, which became the most important agents of liberalism and bearers of "individual" social property. To sum up, market reform was supported by the leading communist cadres, yet promoted the richer republics of the North (Slovenia, Croatia) and technocrats, who became both a part of the ruling class and representatives of the capitalist tendency. Market socialism created multiple centrifugal forces that worked towards disintegration. In some way we could argue that it took certain negative aspects of market (de)regulation and state correctives (taking responsibility for bad investments), while we might also say that this period succeeded more in the expansion of the model of self-management to other, non-economic activities, amongst which cultural production is one important field and example.

\section{Cultural Policy in Yugoslavian Cinematography: From Film Infrastructure to "Techniques to the People"}

How was the transition to self-managing forms of organisation achieved in the cultural field? In this section I intend to illustrate changes in the marketization of social ownership on the field of film infrastructure and production. Katja Praznik's recent illuminative dissertation sketches the institutional frame and shifts within cultural organisations in the following manner:

- up until 1948 cultural matters were strictly regulated through the "federal ministry of culture and each republic's ministry of education (...). In combination with popular committees on three levels" (Praznik 2013: 108). This also meant a very centralized funding system with strong ideological control. ${ }^{10}$

- between 1953 and 1974 political authority instead of federal and republican authority implemented executive "councils and commissions for education and culture, where the president and parts of the members were nominated by government, whereas others were delegated to associations and cultural institutions" (2013: 108-109);

- from 1974 till 1989 instead of a municipal committee and republican council, regulation came into the hands of the municipal cultural community and cultural community of each republic, where members were voted in through the council of (cultural) users and producers (ibid.: 109).

In the field of cinematography and generally in culture, the infrastructure after WWII was completely destroyed, thus it had to be re-built. Also, Yugoslav film had no serious nor longterm film production or dissemination before WWII (Šentevska 2012: 96-100; Goulding 2002: 1-61). In line with the above categorization, the sphere of culture was at first strongly connected to state regulation and the ministry of culture, which in practice meant saturation and the impregnation of all cultural products with propagandistic and ideological means. However, at the congress of writers in 1952, Miroslav Krleža's intervention stated a clear rejection and abandoning of socialist realism from the cultural workers themselves; this would be generally referred to as the opening up to a socialist aesthetic modernism, which promoted the independent path of Yugoslavia into socialism (Goulding 2002; Zimmerman 2010).

${ }^{9}$ For more on the structural changes see chapter 7 of my dissertation (Kirn 2012a).

${ }^{10}$ See Gabrič (1995) and Goulding (2002). 
Nevertheless, as early as in 1946 the Party instituted a cultural policy called "Technique to the People", which later yielded unanticipated effects. The socialist authority established a special institution "Narodna Tehnika" (the Popular Engineering Society), which concentrated on amateur and informal radio, ${ }^{11}$ as well as photographic and film infrastructure and other activities. At this point the ministry for culture remained in charge of larger investments, the building of infrastructure and ideological control, while in the 1950s, it was substituted by the municipal and local communities. The latter were expected to be involved in setting up the cultural infrastructure in such away as to enhance the mediation and socialisation of technology. Ana Janevska's recent study noted that the major aim of the policy “Technique to the People" was to "organize, sponsor and promote different amateur activities. Even though they were under the 'political' control of the centre and were hierarchically organized, they were mostly left to their own devices as peripheral 'amateur reservations'"(2012: 4). From the late 1950s onwards this "hierarchical" and "political" control relaxed and agit-prop commissions were dissolved. ${ }^{12}$ This does not mean that the Yugoslav political leadership no longer attempted to discursively set certain guidelines, but it would be erroneous to speak of an atmosphere of complete repression and the absence of freedom.

There were two further important changes in the 1950s in the field of the film industry. First, the totality of film activity was reorganized in three areas. As Ian Goulding described film production fell

under the category of economic activity with "special cultural significance"; film trade under the category of domestic and international commerce; and networks of film distribution and theatrical shows under the category of "service activities of a communal character". ${ }^{13}$

These changes would in reality result in a transformed "tripartite division" of labour in film activities: a) "enterprises and workers involved in technical bases of film"; b) film studios that would allocate economic resources, contract personnel, services ... [which] "became the sole owners of the finished film", and finally c) "free associations of film-artistic workers". ${ }^{14}$ These artistic workers were from the 1950s onwards positioned as "freelance" workers, who entered into short-term contracts with the film studios. In this tripartite system everything revolved around the film studios.

The last big legal change formalized these processes in 1956 when the Basic Law on Film was introduced. Apart from the funding via republics, the law instituted a differentiated system of "self-financing", which would transfer $15 \%$ of film admission tickets directly to the film production. Decentralisation in the early years also meant the downsizing of the first big film studio, as the other film studios started to operate in all other republics. Due to opening up to the West, the improved Yugoslavian film infrastructure yielded a large growth in audiences; the profit gained by this was transferred back to domestic film production. ${ }^{15}$

In the improved economic conditions and conscious investment in domestic production and with the strengthened activity of film theory and criticism the grounds were prepared for the emergence of the most productive period in the history of Yugoslav film.

\footnotetext{
${ }^{11}$ Nek se čuje i naš glas is an amazing short documentary by Krsto Papić, which shows that the period of the 1960s was marked by a creative proliferation of pirate radio stations developed in the countryside, where people were broadcasting on a diverse range of subjects from music and recipes, to shows and political discussions. It is this popular activity that came into conflict with the official licensing authorities that would give away the frequencies.

${ }^{12}$ See also Aleš Gabričs (1995) study on the specific ideological contours of cultural policy.

${ }^{13}$ Goulding (2002: 35, emphasis added).

${ }^{14}$ Goulding (2002: 35-36).

${ }^{15}$ Goulding (2002: 37-38).
} 


\section{Cinema Clubs as Preparatory Grounds for the Film Explosion: The Unveiling of the Paradox of Self-Management?}

Despite the importance of this legal and economical infrastructure that was organized by the state and republics, we ought to bring into account yet another important grassroots selfmanagement infrastructure, which played a huge role in the development of the new Yugoslav film. Ana Janevski analyzed an almost forgotten part of Yugoslav film history: cinema clubs. ${ }^{16}$ Cinema clubs emerged in all big Yugoslav cities: Split, Novi Sad, Zagreb, Belgrade, Ljubljana, Sarajevo etc. They were social spaces where people watched films together and engaged in (in)formal discussions, via self-organized education. It was in these clubs, where the underground, experimental and amateur young people started work on interdisciplinary projects that would bridge cinema with other arts and media. Aside from their primary function regarding the socialisation of technology and cinematography, cinema clubs also worked as small independent production units. Amateur cinema received public assistance and young directors often worked with $8 \mathrm{~mm}$ and $16 \mathrm{~mm}$ film tapes. Many of the amateurs and self-educated film-makers from these cinema clubs later became internationally renowned film-makers. ${ }^{17}$ Importantly, cinema clubs were crucial spaces where alternative and low-budget film festivals took place: first, there were festivals of amateur film that rotated between cinema clubs and created the film platforms for all-Yugoslav discussion and amateur production; and second, in 1963 Zagreb's cinema club launched the GEFF: the biannual Genre Experimental Film Festival. ${ }^{18}$ Janevski rightly asserts that GEFF's inclination "to connect all human activities was expressed, not only in the field of art, but in science and technology as well, overlapping with broader world tendencies and interest in film as a subject of historical and theoretical research" (2012: 16). Cinema clubs assumed multiple roles and functioned both as a creative experimental laboratory for new practices on the one hand and as a specific self-management amateur production unit on the other.

There are competing interpretations concerning the naming, timing and even method of the new Yugoslav film-Black Wave. ${ }^{19} \mathrm{I}$ arguably pick the year 1963 as the founding year of this new Yugoslav film. In this year three young film-directors: Živojin Pavlović, Marko Babac, and Kokan Rakonjac - directed their second omnibus City. ${ }^{20}$ The film was officially banned. What followed is particularly illuminating for one of the central paradoxes of Yugoslav selfmanagement. The banning of this film led many to expect and suspect that a tough repression of the flourishing arts at that time would ensue,${ }^{21}$ possibly leading to a crackdown on cinema clubs and all critical film production. To the contrary, the next 10 years became the most exciting years in the whole history of Yugoslav film and became referred to as a "golden age" of Yugoslav film. ${ }^{22}$

Apart from assigning cinema clubs and underground cultural milieu an important role, this paradox further proves the inadequacy of the binary opposition between underground

\footnotetext{
${ }^{16}$ Ana Janevski (2012: 4-16). See also the catalogue of the exhibition on cinema clubs, edited by Piškur and Soban (2011). It is noteworthy that also in other Western and Eastern countries cinema clubs existed and provided a strong basis for cinephilic culture.

${ }^{17}$ As early as 1955 Dušan Makavejev filmed PEČAT, whilst Kokan Rakonjac directed BELA MARAMICA.

${ }^{18}$ It was held in 1965, 1967 and 1970.

${ }^{19}$ For an interesting and critical dialogue see especially DeCuire (2010) and Jovanović (2012).

20 Ian Goulding (2002) argues that the Black Wave had already started in 1961 with films that addressed existentialist and romantic themes usually associated with the French new wave. For example, DVOJE (AND LOVE HAS VANISHED) was directed by Aleksandar Pavlović. It unfolds into an existentialist dilemma of a couple, which transforms into a love triangle; another very poetic work is PLES V DEŽJU (DANCING IN THE RAIN), directed by Boštjan Hladnik.

${ }^{21}$ For more information on the flourishing of modernism in Yugoslavia see Germani (2010).

${ }^{22}$ Cf. Vuković (2010: 53).
} 
art (dissident) and official state (repression), which in more recent readings flirts with certain dissident paradigms which place an overemphasis on repression in socialist times. ${ }^{23}$ How could it then be possible that such an immense and critical level of film production was sustained for the whole decade and especially as some of the films openly criticized socialist authority? Pavle Levi (2007) rightly assumes that the existence of these critical films was a sign of freedom in self-management. I would add that the self-management conditions and infrastructure opened ways for more flexible production techniques and the dissemination of movies. What is more, the real paradox lay with the fundamental premises of a socialist authority that (over)valued the role of film in cultural and political education. In this context most of the films received a huge reception and as Želimir Žilnik claims, all critical films received an immense amount of review and (media) coverage. This meant that political authorities were worried about what precisely came onto the (cinematic) screens and therefore invested much effort in persuading those critics of socialist authority that were misrepresenting socialist reality. ${ }^{24}$

Cinema clubs evidently could not be completely autonomous, since they needed to rely on the technical infrastructure that was provided by the major film studios in all the socialist republics (Avala, Viba, Jadran). ${ }^{25}$ The formal infrastructure was used and rented by amateurs from the cinema clubs as well. Žilnik acknowledges: "This was a time when filmmaking was entirely dependent on film technology and infrastructure (...) [which was] not only expensive, but also extremely inaccessible. The process depended on huge laboratories, editing tables and machines that not even all the federal republics had" (2012: 92). Finally, at least two independent and young film-makers every year were given the opportunity to make feature films at the major film studios.

\section{Independent Film Production: Neoplanta as a Paradigmatic Case of Social Ownership in Yugoslav Cinema}

One should also note that from the early 1960s film - like music - benefited progressively from the market reforms, thanks to its relatively well-organised infrastructure. In other words, the fields of music and film developed a certain market with growing audiences, which as sales showed, could be measured not only in the growing domestic market, but also on the international film market. On the one hand this film market entered into Yugoslavia with major co-productions, whilst on the other Yugoslav film production invested in marketing a genre of partisan films, which became its trade-mark. Also, the alternative auteur films travelled to international film festivals. The conditions of "autonomy" within the film field were materially present in the hybrid of market and state support.

Due to the growing flexibility of the economy and the implementation of market criteria, the film industry demanded improved financial revenues. The big film companies thus demanded an even more precarious contractual relationship for many of the young directors. Such a contract openly stated the financial plan and willingness of the film-directors to invest their own work in advance as part of their starting capital, or they were asked to take a loan from the bank. If the film was successful in awards and sales, then the film-author would

\footnotetext{
${ }^{23}$ For the critique of this binarism see Kirn (2012b) and Jovanović (2012).

${ }^{24}$ See our interview with Žilnik in Kirn et al. (2012), and Žižek's point that differentiates communism from fascism in aspects of political education and the Enlightenment tradition.

${ }^{25}$ Mila Turajlićs film Cinema Komunisto presents the scope of the film studio Avala.
} 
receive some of the gained surplus value. This is why it was so important to have a good film collective and a solid financial plan. ${ }^{26}$ Co-production between different republics became one of the possible organisational principles of alternative film production. In the year 1968 for example, the film output was enormous, numbering thirty-two domestic films and nine co-productions.

The self-management model as mentioned before was particularly harsh towards the film workers in the tripartite division of labour, which on the one hand pushed workers into more precarious and flexible positions, whilst on the other hand, it also pushed them to start improving their own political organisation. Film-workers could create film collectives and also participate in the new independent film production companies. By the end of the 1960s there was an emergence of new film companies, which undermined the binary relationship between cinema clubs and large republican film studios. The most famous examples of these film companies were Novi Sad's Neoplanta (Žilnik, Godina, Makavejev, and many others worked there), and in the 1970s Belgrade's Art Film 80 ("Prague school"). Neoplanta was of major importance for the late phase of "new Yugoslav film", where political authorities sharpened their attack and stigmatised them as "Black Wave" ${ }^{27}$ It is not coincidental that a large majority of the Black Wave films and short critical films were completed in Neoplanta.

In order to gain a better understanding of the functioning of Neoplanta, I would like to shortly present a financial/budgetary overview that we published in the book Surfing the Black, which synthesizes five years of Neoplanta's activities (1966-1971; 2012: 159-160). In short, one can define six different sources of revenue for Neoplanta: the Fund for Cinematography from the Socialist Republic of Serbia; the Fund for Culture from the Socialist Autonomous Province of Vojvodina (two feature, six short and two animated films per year); profit from past feature films from Neoplanta; an honorarium for commissioned films; the production of film documentation (regarding the construction of large objects and urban development of cities); and lastly collaboration and work on projects for Television Belgrade and Novi Sad. Since the budget for short films was smaller, I will only comment on the production costs and revenues from seven feature films: Sveti pesak, Lepa parada, Rani radovi (Želimir Žilnik), Samrtno prolece, W.R. Misterije organizma (Dušan Makavejev), Dorucak s djavolom, and Sloboda ili strip (the latter was never finished, directed by Žilnik and Godina). The financial picture was as follows: Neoplanta invested 7,074 809 Yugoslav dinars (at the then existing exchange rate, this would have meant around 416 thousand dollars) and at the end of the cycle they received 2.041,993 dinars (around 120.117 dollars) of added value and profit, which implies a yearly net income of around 25 thousand dollars. Part of the profit was re-invested in the film process, while the other part was given to film workers. What can be found from this 500-pages long document is that the Fund of Province (27\%) and Neoplanta's own funds (36\%) covered the major part of investments, while the remainder came from co-productions.

This technical and financial detour into cost-revenue analysis indicates that independent film production was sandwiched between the federal and republic funds, and that their own funds accumulated from their participation in sales and the receiving of (market) awards. I name this phenomenon a peculiar kind of "public-private" partnership, whereby market self-management entered into relation with state organized cultural activities. This mixed economy could only, to a certain degree, be "adopted" by other cultural activities. A good example would be the emerging musical industry epitomized by major festivals such as "Song

${ }^{26} \mathrm{Cf}$ our interview with Žilnik (2012).

${ }^{27}$ I explain the dilemma surrounding the name Black wave elsewhere (see Kirn 2012b). 
of the year" which gathered audiences of tens of thousands in and around 40-50 major cities across Yugoslavia. Yet most of the other cultural fields, such as theatre, opera and ballet were supported by the budgets at the municipal and republican levels and could not operate in such a semi-autonomous manner. ${ }^{28}$

From the 1970s onwards, apart from the afore-mentioned system of "self-financing", I would like to add another important system of financing in the form of "self-contribution". It was very often the case that citizens of municipalities held referenda, which decided on the building of the self-management infrastructure: from kindergartens, schools and hospitals to cultural centres and small theatres, etc. Instead of waiting for the state to take the initiative, it was citizens who took it: obviously a portion of their own salaries were already being invested in communal areas, such as social housing ${ }^{29}$ and cultural and welfare activities. However, the referenda were at that point not only the sign of larger citizens' participation, but were also a way to gather and redistribute the financial means. One of the positive aspects of such self-managed forms of organisation was that it inscribed a mechanism of collective solidarity in the centre of its financial redistribution, and hence moved beyond a mere individual charity principle or state initiative. However, the downside of the system of self-contributions consisted in them being site-specific, meaning that the richer regions and republics would be able to invest in more and better infrastructure. Also, in times of crisis there would be a tendency to invest less in infrastructure.

\section{Specific Self-managed Political Forms in Culture: Between Improved Institutional Frameworks and Privileged Access to the Financial Circuit (National Culture)}

Katja Praznik's study illustrates clearly that cultural policy and the framework and capacities of cultural institutions were constantly changing, even if the tendency towards the production of an autonomous field of culture remained a driving feature in the socialist period. If this general tendency is true, let me highlight a few specificities, which in the period after market reform, and in particular during the 1970s, relatively improved the institutional framework, and even "democratized" the process of decision-making. What unfolded in the 1970s was the material transfer of financial capacities to lower levels of cultural institutions. Thus, now instead of the ministry of culture at the level of the republic distributing the budget, one needed to then take into account the "Communities of Culture", which were institutions of cultural users and cultural producers, and which was chiefly responsible for the basic outlines and decisions of financing the cultural institution and finally choosing of programs. This would be then branched out both for specific cultural activities and in terms of regional territorialisation. Žilnik was -among other things - a president of the Commission of cinematography for the "community of culture" in Vojvodina (one of the autonomous regions in Yugoslavia). The Commission consisted of one delegate for film distribution in Vojvodina, one delegate from television, one delegate from the cultural centres and several delegates composed of film authors and producers. Once the Commission had received the

\footnotetext{
${ }^{28}$ An interesting development can be traced here in the Yugoslav historiography, especially with respect to the "memorial genre" of monuments to the revolutionary/national liberation struggle. One of the major studies on the institutional and financial aspects has been undertaken by Heike Karge (2010).

${ }^{29}$ The most important study on social housing and how the self-management regulations affected or influenced what happened in reality has been written by Dubravka Sekulić (2012).
} 
projects Žilnik said, "we will make decisions on allocating funding according to creativity, reflexivity, but also the potential financial revenue of these subjects." ${ }^{30}$ Apart from these communities and commissions there were also influential congresses of cultural action, which were varieties of meetings concerning how to self-manage cultural activities. The representatives of the ministries and municipalities explained the functioning of the financial system and in what ways work would be organized, and from these reports with statistical data were then produced. Also, there existed a network of Offices for Culture that researched the system and finances of the cultural field.

Commissions and especially the cultural communities were other names for the "selfmanaged communities of interest", which practiced "double representation" also in the apparatus of social and cultural services. As stated in Žilnik's example, this would mean having delegates from different parts of the cultural field and orchestrating constant communication between producers and users in order to avoid top-bottom directives from one "centre" and financing without consultation. Lev Kreft, a philosopher of aesthetics, was active in the drafting of official cultural policy from the 1970s onwards and described one of the positive tendencies of self-management in the field of culture. At the start of the 1970s increasingly fewer financial capacities were allocated by the ministry of culture (from the republic), in Kreft's words:

the economy of culture became of a much better quality once the financial components and discussions had been transferred to the self-managed communities of interest. In the field of culture these self-managed communities of interest worked fairly well during the 1970s, both on the republican (Slovenian) level and in Ljubljana, as they could afford to cover not only a large part of the national cultural institutions, but also the majority of what was then alternative, non-institutional culture in Ljubljana. In those times the functioning of cultural activities, both in terms of open, democratic and transparent discussion as well as financing was better organized than during the 1960s, and also better than afterwards in the transition during the 1990s.

We have to also keep a critical distance from the institutional and legal aspect of self-management, which unquestionably in its ideal form strived to improve and extend self-management rights from the sphere of production to the sphere of reproduction and non-economic activities. However, one should also not forget that in political practice, the plurality of selfmanagement forms did not always match according to the letter and spirit of the law. In reality, this meant that there was a strong privileging of mainstream institutions of national culture, and Čopič argues that there was a "mixing of interests between users and producers" (1997: 73), where partial interests rather than general interest would be discussed. Also, at least for many independent cultural workers there was highly "unequal access to public financing" (1997: 80): if one belonged to one of the major theatres or other elite cultural institutions, one had a structurally privileged position relative to those who belonged to the sphere of non-institutional and alternative cultural agencies. Despite the fact that the initiative was progressively transferred to the level of "self-managed individuals" and cultural collectives, the amount of finances marked for culture remained the same. As Praznik states, in the late 1970s in the Slovenian republic this amounted to around 4\% of BDP (2013: 105). Moreover, in the cultural institutions, one did not always find an active and constantly debating set of delegates. To sum up, if it is true that in the 1970s in particular the sphere of cultural activities had been institutionally improved and was wheeling between the state, self-man-

${ }^{30}$ From a personal correspondence with Želimir Žilnik. 
aged interest communities and market, ${ }^{31}$ in its material politics the accessibility and level of public finances for culture remained limited. There was more influence over discussions and the distribution of funds, and also as we saw, there was a possibility of "self-contributions" from citizens. However, with the growth of the cultural field (the number of association and cultural workers grew steadily), there was a strong pattern of reproduction as concerns privileged cultural institutions.

So far very little scholarly attention has been given to the precarious conditions of the cultural worker in socialist times apart from some observations made by Boris Buden (2009) and Pavle Levi (2007). The perspective of the cultural worker is one of particular relevance, because it embodies a limit case in the more general system of socialist employment. Susan Woodward (1995) pointed out that Yugoslav economic policy focused primarily on those who were employed in the social sector, that is, those with a regular salary and all social benefits, while it ignored the private sector and forms of seasonal, temporary and/or flexible employment, and most of all unemployment, which from 1960s onwards became a serious problem. The cultural worker in some sense internally subverted, or anticipated the figure of the self-manager as a flexible and precarious worker with few securities that was so well explained in the literature of (post) operaist thinkers, such as Toni Negri, Paolo Virno, Sergio Bologna and others. Here I would like to highlight that in the cultural sphere, and in particular in the case of film, the more flexible labour relationship became a reality as early as the late 1950s. In the words of Pavle Levi:

Workers' councils were thus introduced as decision-making bodies overseeing film production, distribution, and exhibition, while the creative personnel associated with the process of filmmaking (directors, cinematographers, screenwriters) were given the status of freelance professionals. (2007: 15)

This free-lance position was formally given to some artists and cultural workers by the Ministry of Culture. However, we can speak of the proliferation of cultural associations and independent cultural workers only in the late 1970s/1980s. The freelance status evidently did not just mean a (flex)secure and autonomous position that would be emancipated from the state, but had to do with an intensified precarious position, that did not enjoy the same social benefits as other regular jobs meaning lower pensions and often unpaid holidays (see Praznik 2013: 95-101). This precarious status affected socialist cultural workers in various collaborations ranging from amateur cultural associations, to more established galleries, academies, and bigger cultural institutions. This resulted in what is today best known as irregular work on projects. And in this respect, there is no difference between the features from the postsocialist epoch, or their Western counterparts; that is, cultural work consisted of seasonal and intense work in some periods, and times of unemployment in other periods. Apart from this certain groups of cultural workers and cultural institutions enjoyed a large degree of autonomy and a relatively solid material subsistence - in particular, the younger generation - and a more independent alternative culture even if this remained within a set of constraints that should not be idealized.

\footnotetext{
${ }^{31}$ There is also an extensive study by Stevan Majstorović (1980), which addresses some of the major issues of cultural policy and cultural activities in Yugoslav self-management.
} 


\section{Final Remarks}

This contribution shed some light on the hybrid of social ownership that developed in Yugoslavia from the late 1950s to the early 1970s in the area of film activity. My analysis concludes that the cultural self-management infrastructure was well functioning in the 1960s and -due to stable economic growth - film studios, cinema clubs, and independent film studios created a complex web of social relationships without which we cannot fully understand this most exciting period in the history of Yugoslav film. Moreover, the new Yugoslav film industry was able to acquire a relative autonomy from the state, since it developed a complex web of private-public financing initiative and was even scoring profits from production of films. This self-managed cultural autonomy can be understood both as a part of more flexible market reforms and official cultural policy. However, I have also suggested that it be read along the lines of collective organizational efforts on the part of film workers (e.g. Neoplanta) and improved conditions regarding cultural infrastructure. In many respects this ambivalent organization of the film field, an in-betweeness between the informal and formal, on the one hand pointed to flexibility and the more precarious position of the film workers, whilst on the other hand it also offered a platform for critical and internationally renowned films. It was in this contradictory movement that I located the paradox of social ownership in film activity within the stable and well functioning cultural infrastructure.

Despite my criticism of certain proto-capitalist tendencies following the market reform in 1965, I nevertheless evaluate the changes positively, at least in the cultural sphere, as part of a conscious move towards the empowerment of self-managing communities of interest. This move actually enabled a far more transparent and democratic system of financing (and discussion over those) of the cultural activities. However, yet again, despite this institutional flexibility, the system still reproduced general inequalities within the cultural sphere (i.e. dominant cultural institutions versus alternative), and did not ward against the growing precarity of many cultural workers. This paradoxical movement of self-managed film activity rather than returning to the tropes of "repression" and "dissidence" - points to the structural problems after 1965: market reform; the introduction of television (Goulding 2002: 64-65); and finally the pervasive ideology of national culture(s) within the republics that granted privileged access to established genres and institutions. This can shed some further light on our understanding of the current post-socialist condition, which rather than constituting definite break from the 1980 s compared to the 1990 s, could be seen as a radicalization of the processes from the later socialist period.

\section{REFERENCES}

Bajt, Aleksander. 1975. "Social Ownership-Collective and Individual”. In Self-Governing Socialism. A Reader, 2. B. Horvat, M. Marković and R. Supek, eds. New York: International Arts and Sciences Press, 151-164.

Buden, Boris. 2009. Zone des Übergangs. Vom Ende des Postkommunismus. Frankfurt am Main: Suhrkamp.

Čopič, Vesna and Gregor Tomc. 1997. Kulturna politika v Sloveniji: I. Nacionalno poročilo o kulturni politiki v Sloveniji. Ljubljana: Fakulteta za družbene vede.

DeCuir, G. Jr. Winston. 2010. ”Black Wave Polemics. Rhetoric as Eesthetic”. Studies in Eastern European Cinema 1/1: 85-96. [http:// dx.doi.org/10.1386/seec.1.1.85/1]

Dolenec, Danijela and Mislav Žitko. 2013. “Ostrom and Horvat. Identifying Principles of a Socialist Governmentality”. Group 22 Working Paper Series. Available at: www.grupa22.hr.

Flaherty, Diane. Self-management and Requirements for Social Property. Accessible at: http://biblioteca.clacso.edu.ar/ar/libros/ cuba/if/marx/documentos/22/Self-Management\%20and\%20requirements\%20for\%20social\%20.pdf.

Gabrič, Aleš. 1995. Socialistična kulturna revolucija: Slovenska kulturna politika 1953-1962. Ljubljana: Cankarjeva založba.

Germani, Sergio. 2010. “Jugoslavija - misterije organizma”. Upఓ Underground 17/18: 265-292. 
Goulding, Daniel. 2002. Liberated Cinema. The Yugoslav Experience 1945-2001. Bloomington and Indiannapolis: Indiana University Press.

Hardt, Michael and Antonio Negri. 2009. Commonwealth. Cambridge MA: Harvard University Press.

Harvey, David. 2009. “Commonwealth. An Exchange”. Artforum 48/3: 210-221.

Janevski, Ana. 2012. "'We Can't Promise to do More than Experiment'. On Yugoslav Experimental Eilm and Cine Clubs in the Sixties and Seventies". Quaderns portàtils. Barcelona: MACBA.

Jovanović, Nebojša. 2012. “A Commentary on 'Black Wave Polemics. Rhetoric as Aesthetic' by Greg DeCuir”. In Studies in Eastern European Cinema 2/2: 161-167.

Karge, Heike. 2010. Steinerne Errinerung - versteinerte Errinerung?. Harrassowitz: Wiesbaden.

Kirn, Gal. 2012a. Conceptualisation of Politics and Reproduction in the Work of Louis Althusser. Case of Socialist Yugoslavia. Dissertation Thesis: University of Nova Gorica.

Kirn Gal. 2012b. "New Yugoslav Cinema. A Humanist Cinema? Not Really". In Surfing the Black. Black Wave Cinema and its Transgressive Moments. G. Kirn, D. Sekulić and Ž. Testen, eds. Maastricht: JvE Academy. 10-46.

Komelj, Miklavž. 2009. Kako misliti partizansko umetnost? /How to Think Partisan Art? Ljubljana: Založba cf.

Kosanović, Dejan. 1966. Dvadeset Godina jugoslovenskog filma, 1945-1966. Belgrade: Savez filmskih radnika Jugoslavije.

Levi, Pavle. 2007. Disintegration in Frames. Stanford: Stanford University Press.

Majstorović, Stevan. 1980. Cultural Policy in Yugoslavia. Self-Management and Culture. Paris:UNESCO.

Marković, Mihailo. 1975. "Philosophical Foundations of the Idea of Self-management”. In Self-Governing Socialism. A Reader, 1. B. Horvat, M. Marković, and R. Supek, eds. New York: International Arts and Sciences Press, 327-350.

Močnik, Rastko. 2010. “Excess Memory”. http://www.transeuropeennes.eu/en/articles/202/Excess_Memory.

Ostrom, Elin. 1990. Governing the Commons. The Evolution of Institutions for Collective Action. Cambridge: Cambridge University Press. [http://dx.doi.org/10.1017/CBO9780511807763]

Praznik, Katja. 2013. Intelektualno gospostvo. Sodobna umetnost med vzhodom in zahodom, Filozofska Fakulteta: Ljubljana.

Rancière, Jacques, 2012, “On the Actuality of Communism”. In Post-Fordism and its Discontents. G. Kirn, ed. Maastricht: JvE Academy, $127-138$

Rus, Veljko. 1988. "Neekonomski vidiki lastništva”. Družboslovne Razprave, 6/1: 5-22. http://druzboslovnerazprave.org/clanek/ pdf/1988/6/1/.

Samary, Catherine. 1988. Le marché contre l'autogestion. L'expérience yougoslave. Paris: Publisud.

Šntevska, Irena. 2012. “Celluloid Building Sites of Socialist Yugoslavia. Cinema Fiction and Unfinished Modernisations”. In Unfinished Modernisations. Between Utopia and Pragmatism. V. Kulić and M. Mrduljaš, eds. Zagreb: CCA, 96-120.

Sekulić, Dubravka. 2012. Glotz Nicht so Romantisch. Maastricht: JvE Academy.

Suvin, Darko. 2011. “Ekonomsko-politicke perspektive Borisa Kidriča”. Zarez 308: 10-11.

Suvin, Darko 2014, Samo jednom se ljubi. Radiografija SFR Jugoslavije. RLS: Belgrade.

Vilenica, Ana and kuda.org. 2012. "Preuzmimo grad! Kako?" In Na ruševinama kreativnog grada. Ana Vilenica and kuda.org, eds. Novi Sad: Centar za nove medije_kuda.org. http://www.kuda.org/na-ru-evinama-kreativnog-grada-zbornik-0.

Vuković, Stevan. 2010. "Notes on Paradigms in Experimental Film in Socialist Yugoslavia”. In This Is All Film! Experimental Film in Former Yugoslavia 1951-1991, exhibition curated by Bojana Piškur, Ana Janevski, Jurij Meden and Stevan Vuković. Ljubljana: Museum of Modern Art Ljubljana.

Woodward, Susan. 1995. Socialist Unemployment. The Political Economy of Yugoslavia 1945-90. Princeton: Princeton UP.

Zimermman, Tanja. 2010. “Novi kontinent - Jugoslavija. Politična geografija 'tretje poti'”. Zbornik za umetnostno zgodovino. Archives d'histoire de l'art, n. s. XLVI, 165-190.

\section{Interviews}

“Those Who Make Revolutions Only Halfway Dig Their Own Graves, interview with Želimir Žilnik”, Surfing the Black. Black Wave Cinema and its Transgressive Moments. Gal Kirn, Dubravka Sekulić and Žiga Testen, eds. Maastricht: JvE Academy, 10-46.

Personal correspondence with Želimir Žilnik and Lev Kreft. 
GAL KIRN. A Few Notes on the History of Social Ownership...

\section{Nacrt za razumijevanje društvenog vlasništva te sfere kulture i filma u socijalističkoj Jugoslaviji u razdoblju 1960-1970}

\section{Sažetak}

Ovaj tekst kritički propituje kako se ideja samoupravljanja mijenjala i konkretizirala u Jugoslaviji posebice tijekom šezdesetih i sedamdesetih godina dvadesetoga stoljeća. U prvom dijelu rada daje se pregled politike samoupravljanja te njezinog paradoksalnog i kontradiktornog razvoja. Drugi dio se fokusira na ocrtavanje jugoslavenske kulturne sfere posebno u/na području filma u razdoblju od kasnih pedesetih do ranih sedamdesetih. Točnije, autor pokušava ocrtati načine na koji su se društveno vlasništvo i samoupravljanje upisali u kulturnu infrastrukturu, planiranje budžeta, ukazujući na prekarni status rada u kulturi.

Ključne riječi: jugoslavensko samoupravljanje, društveno vlasništvo, kulturna infrastruktura, filmska industrija, 1960te-1970te, rad u kulturi 